\title{
OPTIMASI KONSENTRASI PELARUT DAN WAKTU EKSTRAKSI PEKTIN KULIT JERUK MANIS (CITRUS SINENSIS) DENGAN METODE MASERASI
}

\section{Optimization of Solvent Concentration and Duration in the Pectin Extraction from Sweet Orange Peels (Citrus sinensis) using Maceration Method}

\author{
Widya Dwi Rukmi Putri*, Anggi Triwardiningsih Nasution, Margaretha Hanna Tiffani, \\ Aditya Wardana \\ Jurusan Teknologi Hasil Pertanian - Fakultas Teknologi Pertanian - Universitas Brawijaya \\ Jl. Veteran - Malang 65145 \\ *Penulis Korespondensi, email: widya2putri@ub.ac.id
}

Disubmit: 6 Januari 2021 Direvisi: 22 Februari 2021 Diterima: 16 April 2021

\begin{abstract}
ABSTRAK
Limbah kulit jeruk dapat dimanfaatkan menjadi pektin dengan cara diekstrak. Pektin banyak digunakan pada industri pangan, salah satunya stabilizer. Penelitian bertujuan mengetahui konsentrasi pelarut dan lama waktu yang optimum pada proses ekstraksi untuk mendapatkan rendemen, total pektin, dan tingkat kecerahan yang terbaik. Rancangan penelitian menggunakan Response Surface Methodology dengan Central Composite Design melalui software Design Expert 7.1.5. Kombinasi faktor perlakuan yaitu, konsentrasi asam oksalat (\%) dan lama waktu ekstraksi (menit). Hasil penelitian menunjukkan nilai optimum konsentrasi pelarut asam oksalat sebesar 0,22\% dengan lama waktu ekstraksi 90 menit 16 detik, menghasilkan 16,78\% rendemen; 10,59\% total pektin; dan 63,56 (L) tingkat kecerahan pektin. Kemudian, dilakukan karakterisasi pektin optimasi dengan hasil untuk kadar air 9,87\%, berat ekivalen 901,60; kadar metoksil 5,59\%; kadar asam galakturonat 51,45\%; dan derajat esterifikasi 61,69\%. Pektin yang dihasilkan sudah sesuai dengan standar International Pectin Producers Association (IPPA), kecuali pada berat ekivalen. Pektin hasil optimasi termasuk pektin metoksil rendah

Kata kunci : Ekstraksi; Kulit Jeruk Manis (Citrus sinensis); Pektin; Response Surface Methodology

ABSTRACT

Orange peels waste can be utilized by extracting the pectin. Pectin used by food industry as stabilizer. This research aims to determine the optimum solvent concentration and duration in the extraction process to get the best yield, total pectin, and brightness level of pectin. Design of this study uses Response Surface Methodology with Central Composite Design through Design Expert 7.1.5 software. Combination of factors used are oxalic acid solvent concentration (\%) and extraction duration (minutes). Results of optimum concentration of oxalic acid solvent used for extraction is $0.22 \%$ and optimum time of extraction is 90 minutes 16 seconds, resulting $16.78 \%$ for yield; 10.59\% for total pectin; and 63.56 (L) for brightness level of pectin. The characterization of the optimized pectin are as follows : water content of $9,87 \%$; equivalent weight of 901.60; methoxyl content of 5.59\%; galacturonic acid level of $51.45 \%$; and esterification content of $61.69 \%$. The result of characterizations pectin fitted accordance with the International Pectin Producers Association (IPPA) standard, except for equivalent weight. Optimized pectin classified as low methoxyl pectin type
\end{abstract}

Keywords : Extraction; Sweet peel orange (Citrus sinensis); Pectin; Response Surface Methodology 


\section{PENDAHULUAN}

Jeruk merupakan salah satu hasil perkebunan Indonesia yang memiliki produksi cukup tinggi. Tingginya produksi dan konsumsi buah jeruk diikuti dengan banyaknya limbah yang dihasilkan, salah satunya yaitu kulit jeruk. Kulit jeruk manis merupakan limbah hasil pengolahan sari/jus jeruk yang memiliki kandungan pektin sekitar $25-30 \%$ basis kering (Kute et al., 2019). Pektin adalah senyawa heteropolisakarida larut air (bersifat hidrofilik). Komponen yang paling dominan pada kulit jeruk yaitu pektin, dimana rendemen pektin dari kulit jeruk sebesar $\pm 30 \%$ bobot kering. Hal ini membuat limbah kulitjeruk manis dapat ditanggulangi dengan dijadikan sebagai salah satu bahan baku sumber pektin melalui proses ekstraksi. Pektin merupakan senyawa polimer dari asam galakturonat, turunan galaktosa yang dihubungkan dengan ikatan a-1,4-glukosida. Pektin umumnya digunakan sebagai bahan penstabil pada sari buah, bahan pembuatan jelly, jam, dan marmalade (Rosalina et al., 2017).

Ekstraksi pektin bertujuan untuk memisahkan pektin dari jaringan tanaman. Metode ekstraksi yang banyak digunakan pada industri di Indonesia adalah metode maserasi. Metode maserasi merupakan cara ekstraksi yang sederhana. Keuntungan dari metode maserasi yaitu prosedur dan peralatannya sederhana. Penggunaan asam dalam ekstraksi pektin adalah sebagai pelarut untuk menghidrolisis protopektin menjadi pektin yang larut dalam air. Namun, penggunaan asam mineral kuat kurang efisien karena asam mineral kuat bersifat korosif dan tidak ramah lingkungan (Pereira et al., 2016). Penggunaan asam lemah dapat dilakukan dalam ekstraksi pektin sebagai alternatif dari asam kuat, contohnya asam oksalat

Berdasarkan penelitian terdahulu, menyebutkan bahwa ekstraksi pektin dari limbah kulit jeruk kalamansi dengan metode konvensional menghasilkan rendemen sebesar $15,3 \%$ pada suhu $80{ }^{\circ} \mathrm{C}$ selama 120 menit (Rosalina et al., 2017). Penelitian terdahulu yang dilakukan lebih banyak mengkaji suhu dan lama waktu ekstraksi, sehingga perlu dilakukan penelitian lebih lanjut terhadap faktor lain yang berpengaruh seperti konsentrasi asam dan lama waktu ekstraksi. Konsentrasi asam dan lama waktu ekstraksi berpengaruh terhadap rendemen pektin dari kulit nangka (Windiarsih et al., 2015).
Parameter mutu berupa rendemen dan total pektin dibutuhkan untuk menentukan banyaknya pektin yang didapatkan dan pektin yang murni pada suatu bahan. Selain itu, parameter berupa mutu tingkat kecerahan pektin cukup penting, karena pektin diharapkan tidak mengubah warna produk akhir. Optimasi ekstraksi pektin dengan menggunakan maserasi dengan pelarut asam lemah belum dilakukan oleh peneliti sebelumnya terutama pada ekstraksi pektin kulit jeruk manis menggunakan pelarut asam oksalat. Penelitian ini dilakukan untuk mendapatkan waktu ekstraksi maserasi dan konsentrasi pelarut asam oksalat yang optimal dengan menggunakan metode RSM (Response Surface Methodology), pada respon rendemen, total pektin dan nilai kecerahan.

\section{METODE}

Bahan baku yang digunakan untuk penelitian ini yaitu jeruk manis dengan kulit berwarna hijau kekuningan dengan umur panen 8-9 bulan setelah berbunga, yang diperoleh dari pengepul di desa Selorejo, Kecamatan Dau, Kabupaten Malang, Jawa Timur. Selain itu, bahan kimia yang digunakan untuk ekstraksi yaitu asam oksalat, etanol 96\%, akuades, $\mathrm{HCl} \mathrm{0,05} \mathrm{N,} \mathrm{HCl} \mathrm{0,3}$ $\mathrm{N}, \mathrm{NaOH} 0,1 \mathrm{~N}, \mathrm{CaCl}_{2} 1 \mathrm{~N}, \mathrm{CH}_{3} \mathrm{COOH} 1 \mathrm{~N}$, $\mathrm{NaCl}$, indikator phenolptalein.

Alat yang digunakan pada penelitian ini yaitu, pisau, baskom, shaker waterbath (Memmert), pengering cabinet (lokal), blender kering, ayakan 80 mesh, timbangan digital (Denver instrument M-310), oven listrik 220 volt (Memmert), desikator (Nuceite), kain saring, kertas saring halus, kertas saring kasar, mortar, glassware, colour reader (Konica Minolta CR-10 Japan), shaker (Orbital Genie), sentrifuge (WINA Instrument).

Metode penelitan menggunakan Response Surface Methodology (RSM) dengan rancangan Central Composite Design (CCD) menggunakan piranti lunak Design Expert 7.1.5. Terdapat dua faktor yang digunakan pada desain penelitian yang dilakukan, yaitu faktor konsentrasi pelarut asam oksalat (\%) dan lama waktu ekstraksi (menit). Respon yang digunakan, yaitu rendemen (\%), total pektin (\%), dan tingkat kecerahan pektin (L). Hasil optimasi ekstraksi kemudian diverifikasi dengan membandingkan nilai respon 
penelitian dan nilai respon prediksi program dengan 3 kali ulangan, kemudian dianalisa dengan menggunakan uji $\mathrm{T}$ (T-test). Hasil pektin optimasi dan telah diverifikasi selanjutnya dilakukan karakterisasi diantaranya, kadar air, berat ekivalen, kadar metoksil, kadar asam galakturonat, dan derajat esterifikasi.

Pelaksanaan penelitian dilakukan dua tahap, yaitu penelitian pendahuluan dan penelitian utama. Penelitian pendahuluan dilakukan untuk menentukan variasi konsentrasi pelarut asam oksalat dan lama waktu ekstraksi yang akan digunakan. Penelitian utama dilakukan untuk mengetahui konsentrasi pelarut asam oksalat dan lama waktu ekstraksi yang optimal terhadap rendemen, total pektin, dan tingkat kecerahan pektin pada pektin hasil ekstraksi dari kulit jeruk manis, yang selanjutnya akan dilakukan karakteriasi.

Prosedur analisa yang dilakukan pada bahan baku kulit jeruk meliputi kadar air metode oven (AOAC, 2005) dan total pektin (Renggana, 1997). Analisa pektin hasil ekstraksi dari kulit jeruk manis menggunakan metodologi permukaan respon untuk mengetahui kondisi optimal pada penelitian yang dilakukan. Penelitian ini dilakukan dengan menggunakan software Design Expert 7.1.5 dengan rancangan Central Composite Design (CCD), meliputi rendemen (AOAC, 1984), total pektin (Renggana, 1997), dan tingkat kecerahan pektin (Nurhayati et al., 2016). Solusi optimum yang didapatkan akan di verifikasi dengan uji Paired T-test dengan menggunakan piranti lunak Minitab 17. Selanjutnya dilakukan karakterisasi pada pektin optimum diantaranya, kadar air metode oven (AOAC, 2005), berat ekivalen (Ismail et al., 2012), kadar metoksil (Ismail et al., 2012), kadar asam galakturonat (Ismail et al., 2012), dan derajat esterifikasi (Ismail et al., 2012).

\section{HASIL DAN PEMBAHASAN}

\section{Karakteristik Bahan Baku}

Analisa karakteristik bahan baku kulit jeruk manis meliputi kadar air dan total pektin. Pada hasil analisa yang dilakukan menunjukkan bahwa kadar air kulit jeruk manis sebesar $78,57 \pm 0,26 \%$, sementara untuk total pektin kulit jeruk manis sebesar 2,86 $\pm 0,19 \%$. Kadar air merupakan banyaknya air yang terkandung dalam bahan yang dinyatakan dalam persen. Kadar air dalam bahan pangan ikut menentukan kesegaran dan daya tahan bahan pangan tersebut. Kadar air yang tinggi mengakibatkan mudahnya bakteri, kapang, dan khamir untuk berkembang biak, sehingga akan terjadi perubahan pada bahan pangan (Kusnandar, 2011; Patrigani et al., 2021). Jeruk merupakan buah yang memiliki kandungan pektin yang cukup tinggi, kandungan pektin pada kulit jeruk dapat diperoleh dengan cara diekstrak. Kandungan pektin pada kulit jeruk berpotensi untuk digunakan sebagai gelling agent, emulsifier, stabilizer, dan thickener (Perina et al., 2007). Analisa total pektin pada bahan baku diperlukan sebagai identifikasi awal nilai total pektin. Kadar pektin dari kulit jeruk manis ini lebih rendah dari kadar pektin jeruk manis Nigeria yang mencapai 12,93-29,05\% (Fakayode dan Abobi, 2018). Hasil nilai total pektin dapat terjadi perbedaan karena disebabkan perbedaan varietas bahan baku yang digunakan baik dari tingkat kematangan maupun kondisi iklim atau perbedaan yang terjadi karena perbedaan metode ekstraksi dan metode analisa yang digunakan untuk ekstraksi pektin kulit jeruk manis.

\section{Optimasi Proses Ekstraksi Pektin dari Kulit Jeruk Manis (Citrus sinensis)}

Data hasil analisa optimasi proses ekstraksi pektin dari kulit jeruk manis dengan faktor yang digunakan yaitu konsentrasi asam oksalat dan lama waktu ekstraksi terhadap respon yang dioptimasi adalah rendemen, total pektin, dan tingkat kecerahan dapat dilihat pada Tabel 1. Nilai respon rendemen terendah didapatkan pada ekstraksi dengan konsentrasi asam okslat $0,30 \%$ dan lama waktu ekstraksi 60 menit menghasilkan nilai sebesar $13,55 \pm 0,52 \%$, sementara nilai respon rendemen tertinggi didapatkan pada konsentrasi asam oksalat 0,20\% dengan lama waktu esktraksi 90 menit menghasilkan nilai sebesar $17,48 \pm 0,36 \%$. Nilai respon total pektin terendah didapatkan pada ekstraksi dengan konsentrasi asam oksalat $0,10 \%$ dan lama waktu ekstraksi 60 menit menghasilkan nilai sebesar $5,07 \pm 0,35 \%$, sementara nilai respon total pektin tertinggi didapatkan pada konsentrasi asam oksalat 0,20\% dengan lama waktu ekstraksi 90 menit menghasilkan nilai sebesar $11,37 \pm 0,86 \%$. Nilai respon tingkat kecerahan pektin terendah didapatkan pada konsentrasi asam oksalat 0,20\% dengan lama waktu ekstraksi 132,43 menit menghasilkan 
nilai sebesar $54,34 \pm 0,31$, sementara nilai respon tingkat kecerahan pektin tertinggi pada konsentrasi asam oksalat $0,20 \%$ dengan lama waktu ekstraksi 47,57 menit menghasilkan nilai sebesar $65,98 \pm 0,49$.

\section{Analisa Rendemen}

Pemilihan model terbaik pada respon rendemen pektin didasari oleh analisa jumlah kuadrat dari urutan model (Sequential Model Sum of Squares), pengujian ketidaktepatan (Lack of Fit Test) dan ringkasan model statistik (Model Summary Statistic). Berdasarkan ketiga metode pemilihan model, model kuadratik merupakan terpilih untuk menjelaskan hubungan antara faktor konsentrasi asam oksalat dengan lama waktu ekstraksi terhadap respon rendemen. Hasil analisa ragam (ANOVA) respon rendemen menunjukkan bahwa model kuadratik adalah model yang sesuai dengan respon rendemen. Hal ini ditunjukkan oleh p-value yang memiliki nilai kurang dari $5 \%$ atau $<0,05$ yaitu sebesar 0,0005, artinya model kuadratik memberikan pengaruh yang signifikan terhadap respon rendemen. Setelah itu, didapatkan persamaan model kuadratik terhadap respon rendemen sesuai dengan Persamaan (1).

$\mathrm{Y}=+2,37815+26,99392 \mathrm{X}_{1}+0,22625 \mathrm{X}_{2}+$ $0,21500 X_{1} X_{2}-101,23750 X_{1}^{2}-1,36097 \mathrm{E}-003$ $\mathrm{X}_{2}^{2}$.

Keterangan :

$\mathrm{Y}=$ Rendemen $(\%)$,

$\mathrm{X}_{1}=$ Faktor konsentrasi (\%),

$\mathrm{X}_{2}=$ Faktor waktu (menit)

Berdasarkan Persamaan (1), disimpulkan bahwa nilai respon rendemen akan mengalami peningkatan seiring dengan meningkatnya konsentrasi asam oksalat dengan lama waktu ekstraksi, hal ini ditunjukkan dengan koefisien regresi yang positif. Namun, nilai rendemen akan menurun dengan tingginya peningkatan konsentrasi asam oksalat dan lama waktu ekstraksi, hal ini ditunjukkan koefisien regresi yang negatif. Hal ini sejalan dengan grafik yang dihasilkan (Gambar 1), semakin tinggi konsentrasi asam oksalat dan dan semakin lama waktu ekstraksi akan menghasilkan nilai rendemen yang semakin tinggi sampai mencapai kondisi optimum, setelah mencapai kondisi optimum akan terjadi penurunan rendemen pektin yang dihasilkan seiring dengan peningkatan konsentrasi asam dan lama waktu ekstraksi.
Semakin tinggi konsentrasi asam pada pelarut, dimana ion $\mathrm{H}+$ semakin banyak maka kemampuan asam untuk memutus ikatan selulosa dengan asam asam pektinat akan semakin besar, sehinggga pektin yang teresktrak semakin banyak. Namun, konsentrasi asam yang terlalu tinggi akan menyebabkan terjadinya degradasi pektin, sehingga perolehan rendemen pektin akan menjadi semakin sedikit (Budiyarti et al., 2013). Sementara, pada lama waktu ekstraksi, semakin lama ekstraksi yang terjadi maka rendemen akan semakin meningkat, karena semakin lama ekstraksi maka jaringan tanaman akan semakin lunak, sehingga protopektin yang merupakan senyawa pektin yang tidak larut dalam air yang terdapat di dalam jaringan tanaman akan semakin banyak terhidrolisis menjadi pektin yang larut dalam air (Nuh, 2017). Namun, penambahan waktu ekstraksi tidak sebanding dengan rendemen yang diperoleh. Apabila ekstraksi dilakukan pada pelarut yang telah jenuh. Pelarut yang telah jenuh tidak dapat mengekstraksi lagi atau kurang baik kemampuan untuk mengekstraksinya karena gaya pendorong (driving force) semakin lama semakin kecil. Akibatnya waktu ekstraksi semakin lama dan rendemen yang dihasilkan tidak bertambah lagi secara signifikan.

\section{Analisa Total Pektin}

Pemilihan model terbaik pada respon total pektin didasari oleh analisa jumlah kuadrat dari urutan model (Sequential Model Sum of Squares), pengujian ketidaktepatan (Lack of Fit Test) dan ringkasan model statistik (Model Summary Statistic). Berdasarkan ketiga metode pemilhan model, model kuadratik merupakan terpilih untuk menjelaskan hubungan antara faktor konsentrasi asam oksalat dengan lama waktu ekstraksi terhadap respon total pektin. Hasil analisa ragam (ANOVA) respon total pektin menunjukkan bahwa model kuadratik adalah model yang sesuai dengan respon total pektin. Hal ini ditunjukkan oleh p-value yang memiliki nilai kurang dari $5 \%$ atau $<0,05$ yaitu sebesar $<0,0001$, artinya model kuadratik memberikan pengaruh yang signifikan terhadap respon total pektin. Setelah itu, didapatkan Persamaan (2) model kuadratik terhadap respon total pektin. 
Tabel 1. Hasil analisa respon optimasi proses ekstraksi pektin kulit jeruk manis terhadap konsentrasi asam oksalat dan lama waktu

\begin{tabular}{ccccccc}
\hline & & \multicolumn{2}{c}{ Variabel Aktual } & \multicolumn{3}{c}{ Variabel Respon } \\
\cline { 3 - 7 } Std & Run & $\begin{array}{c}\text { Konsentrasi } \\
\text { Asam Oksalat } \\
(\mathbf{\%})\end{array}$ & $\begin{array}{c}\text { Lama Waktu } \\
\text { Ekstraksi } \\
\text { (Menit) }\end{array}$ & $\begin{array}{c}\text { Tingkat } \\
\text { Kecerahan } \\
\text { Pektin (L) }\end{array}$ & Rendemen (\%) & $\begin{array}{c}\text { Total Pektin } \\
\mathbf{( \% )}\end{array}$ \\
\hline 1 & 7 & 0,10 & 60,00 & $64,46 \pm 0,53$ & $13,95 \pm 0,49$ & $5,07 \pm 0,35$ \\
2 & 4 & 0,30 & 60,00 & $64,19 \pm 0,15$ & $13,55 \pm 0,52$ & $5,80 \pm 0,11$ \\
3 & 11 & 0,10 & 120,00 & $57,68 \pm 0,33$ & $13,89 \pm 0,60$ & $5,92 \pm 0,24$ \\
4 & 1 & 0,30 & 120,00 & $55,28 \pm 0,97$ & $16,07 \pm 0,44$ & $9,82 \pm 0,42$ \\
5 & 6 & 0,06 & 90,00 & $63,70 \pm 0,52$ & $14,22 \pm 0,85$ & $5,32 \pm 0,59$ \\
6 & 13 & 0,34 & 90,00 & $60,24 \pm 0,88$ & $16,27 \pm 0,94$ & $9,85 \pm 0,70$ \\
7 & 10 & 0,20 & 47,57 & $65,98 \pm 0,49$ & $13,63 \pm 0,37$ & $5,20 \pm 0,21$ \\
8 & 3 & 0,20 & 132,43 & $54,34 \pm 0,31$ & $16,01 \pm 0,74$ & $7,83 \pm 0,63$ \\
9 & 5 & 0,20 & 90,00 & $63,36 \pm 0,34$ & $17,48 \pm 0,36$ & $11,37 \pm 0,86$ \\
10 & 8 & 0,20 & 90,00 & $63,98 \pm 0,25$ & $16,81 \pm 0,27$ & $10,88 \pm 0,46$ \\
11 & 9 & 0,20 & 90,00 & $64,07 \pm 0,61$ & $16,60 \pm 0,26$ & $9,93 \pm 1,02$ \\
12 & 2 & 0,20 & 90,00 & $64,06 \pm 0,19$ & $16,73 \pm 0,14$ & $10,27 \pm 0,26$ \\
13 & 12 & 0,20 & 90,00 & $64,03 \pm 0,70$ & $17,06 \pm 0,60$ & $11,15 \pm 0,22$ \\
\hline
\end{tabular}

Tabel 2. Solusi titik optimum ekstraksi terhadap respon tingkat kecerahan, rendemen, total pektin

\begin{tabular}{cccccccc}
\hline No & $\begin{array}{c}\text { Konsentrasi } \\
(\mathbf{\%})\end{array}$ & $\begin{array}{c}\text { Waktu } \\
(\text { Menit) }\end{array}$ & $\begin{array}{c}\text { Tingkat } \\
\text { Kecerahan } \\
(\mathbf{L})\end{array}$ & $\begin{array}{c}\text { Rendemen } \\
\mathbf{( \% )}\end{array}$ & $\begin{array}{c}\text { Total } \\
\text { Pektin } \\
(\mathbf{\%})\end{array}$ & Desirability \\
\hline 1 & 0,22 & 90,27 & 63,61 & 17,02 & 10,95 & 0,87 & Selected \\
\hline
\end{tabular}

Tabel 3. Solusi titik optimum ekstraksi terhadap respon tingkat kecerahan, rendemen, dan total pektin

\begin{tabular}{lccccc}
\hline & \multicolumn{2}{c}{ Variabel bebas } & \multicolumn{3}{c}{ Respon } \\
\cline { 2 - 6 } & $\begin{array}{c}\text { Konsentrasi } \\
\mathbf{( \% )}\end{array}$ & $\begin{array}{c}\text { Waktu } \\
\mathbf{( M e n i t )}\end{array}$ & $\begin{array}{c}\text { Tingkat } \\
\text { Kecerahan }(\mathbf{L})\end{array}$ & $\begin{array}{c}\text { Rendemen } \\
\mathbf{( \% )}\end{array}$ & $\begin{array}{c}\text { Total Pektin } \\
\mathbf{( \% )}\end{array}$ \\
\cline { 2 - 6 } & 0,22 & 90,27 & 63,61 & 17,02 & 10,95 \\
Prediksi * & 0,22 & 90,27 & $63,56 \pm 0,05$ & $16,78 \pm 0,18$ & $10,59 \pm 0,34$ \\
$\begin{array}{l}\text { Verifikasi ** } \\
\text { Hasil Uji T } \\
(p \text {-value) }\end{array}$ & & & $0,234(\mathrm{NS})$ & $0,144(\mathrm{NS})$ & $0,201(\mathrm{NS})$ \\
\hline \hline
\end{tabular}


Jurnal Teknologi Pertanian Vol. 22 No. 1 [April 2021] 47-56

Optimasi Konsentrasi Pelarut dan Waktu Ekstraksi Pektin Kulit Jeruk Manis [Putri dkk]

Tabel 4. Hasil karakterisasi pektin optimasi

\begin{tabular}{lcc}
\hline Parameter & Pektin Hasil Optimasi $\mathbf{1}^{\mathbf{1} 2}$ & Nilai Standar Mutu Pektin $^{3}$ \\
\hline Kadar Air (\%) & $9,87 \pm 0,19$ & Mak 12\% \\
Berat Ekivalen & $901,60 \pm 1,08$ & $600-800$ \\
Kadar Metoksil (\%) & $5,59 \pm 0,11$ & \\
- Pektin Metoksi Tinggi & & $>7,12 \%$ \\
- Pektin Metoksil Rendah & & $2,5 \%-7,12 \%$ \\
Kadar Asam Galaturonat (\%) & $51,45 \pm 0,59$ & Min 35\% \\
Derajat Esterifikasi (\%) & $61,69 \pm 0,46$ & \\
- Pektin Ester Tinggi & & Min 50\% \\
- Pektin Ester Rendah & & Maks 50\% \\
\hline Keterangan:
\end{tabular}

Keterangan:

1. Data pektin hasil optimasi merupakan hasil rata-rata dari tiga ulangan

2. Nilai atau angka dibelakang simbol \pm merupakan standar deviasi

3. IPPA : International Pectin Producers Association (2002)

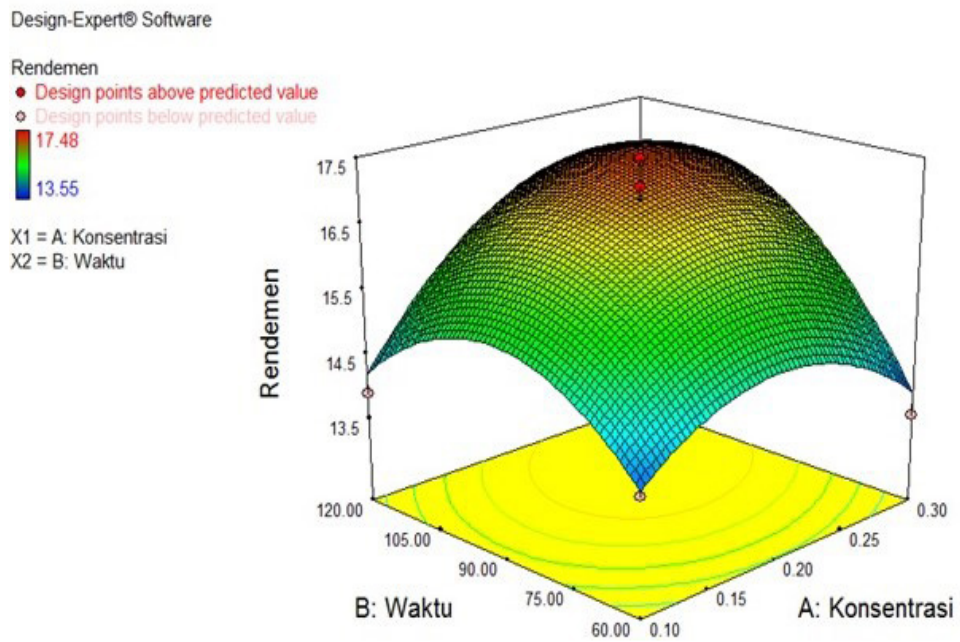

Gambar 1. Grafik interaksi 3-D terhadap rendemen

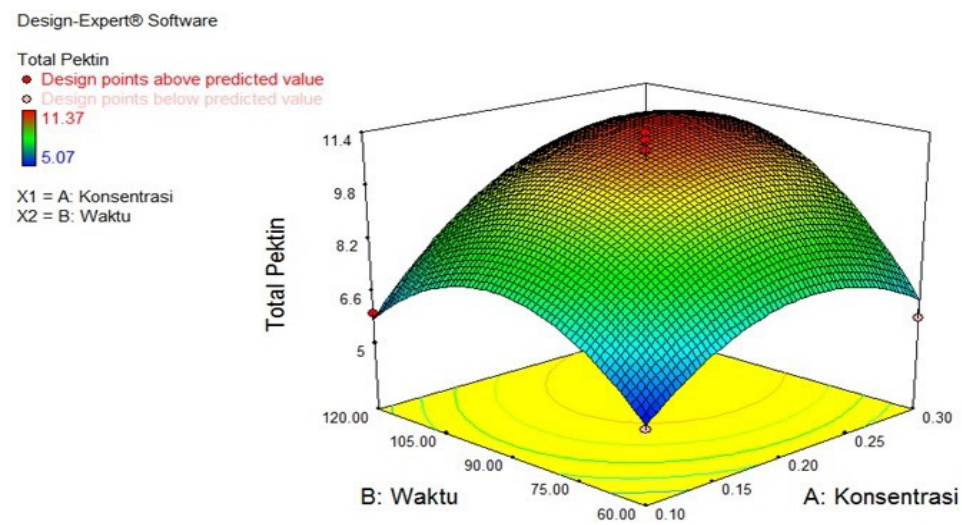

Gambar 2. Grafik interaksi 3-D terhadap total pektin 
$\mathrm{Y}=-16,98949+56,69548 \mathrm{X}_{1}+0,42333 \mathrm{X}_{2}+$ $0,26417 X_{1} X_{2}-166,68750 X_{1}^{2}-2,44653 E-003 X_{2}^{2}$

Keterangan :

$\mathrm{Y}=$ Total Pektin (\%),

$\mathrm{X}_{1}=$ Faktor konsentrasi (\%),

$X_{2}=$ Faktor waktu (menit)

Berdasarkan Persamaan (2), dapat disimpulkan bahwa nilai respon total pektin akan mengalami peningkatan seiring dengan meningkatnya konsentrasi asam oksalat dengan lama waktu ekstraksi, hal ini ditunjukkan dengan koefisien regresi yang positif. Namun, nilai total pektin akan menurun dengan tingginya peningkatan konsentrasi asam oksalat dan lama waktu ekstraksi, hal ini ditunjukkan koefisien regresi yang negatif. Hal ini sejalan dengan grafik pada Gambar 2 yang dihasilkan. Semakin tinggi konsentrasi asam oksalat dan dan semakin lama waktu ekstraksi akan menghasilkan nilai total pektin yang semakin tinggi sampai mencapai kondisi optimum, setelah mencapai kondisi optimum akan terjadi penurunan total pektin yang dihasilkan seiring dengan peningkatan konsentrasi asam dan lama waktu ekstraksi.

Semakin tinggi konsentrasi asam pada pelarut, dimana ion $\mathrm{H}^{+}$semakin banyak maka kemampuan asam untuk memutus ikatan selulosa dengan asam asam pektinat akan semakin besar, sehinggga pektin yang teresktrak semakin banyak. Namun, konsentrasi asam yang terlalu tinggi akan menyebabkan terjadinya degradasi pektin menjadi asam pektat, sehingga perolehan nilai total pektin akan menjadi semakin sedikit (Budiyarti et al., 2013). Sementara, pada lama waktu ekstraksi, semakin lama waktu ekstraksi, maka nilai total pektin akan meningkat karena semakin lama ekstraksi maka jaringan tanaman akan semakin lunak, sehingga protopektin yang merupakan senyawa pektin yang tidak larut dalam air yang terdapat di dalam jaringan tanaman akan semakin banyak terhidrolisis menjadi pektin yang larut dalam air (Nuh, 2017). Namun, waktu ekstraksi yang lebih lama dapat mendegradasi pektin menjadi asam pektat (Kanse et al., 2017). Semakin lama waktu ekstraksi akan membuat kontak asam yang panas dengan substrat semakin lama, sehingga pada kondisi asam akan membuat terhidrolisisnya ikatan glikosidik gugus metil ester dan nantinya menghasilkan asam pektat. Asam pektat merupakan asam poligalakturonat yang tidak teresterifikasi. Apabila terjadi hal ini, maka asam pektat ini akan tidak dapat diendapkan dengan penambahan alkohol, sehingga total pektin yang dihasilkan akan semakin berkurang (Ziari et al., 2010).

\section{Analisa Tingkat Kecerahan Pektin}

Pemilihan model terbaik pada tingkat kecerahan pektin didasari oleh analisa jumlah kuadrat dari urutan model (Sequential Model Sum of Squares), pengujian ketidaktepatan (Lack of Fit Test) dan ringkasan model statistik (Model Summary Statistic). Berdasarkan ketiga metode pemilhan model, model

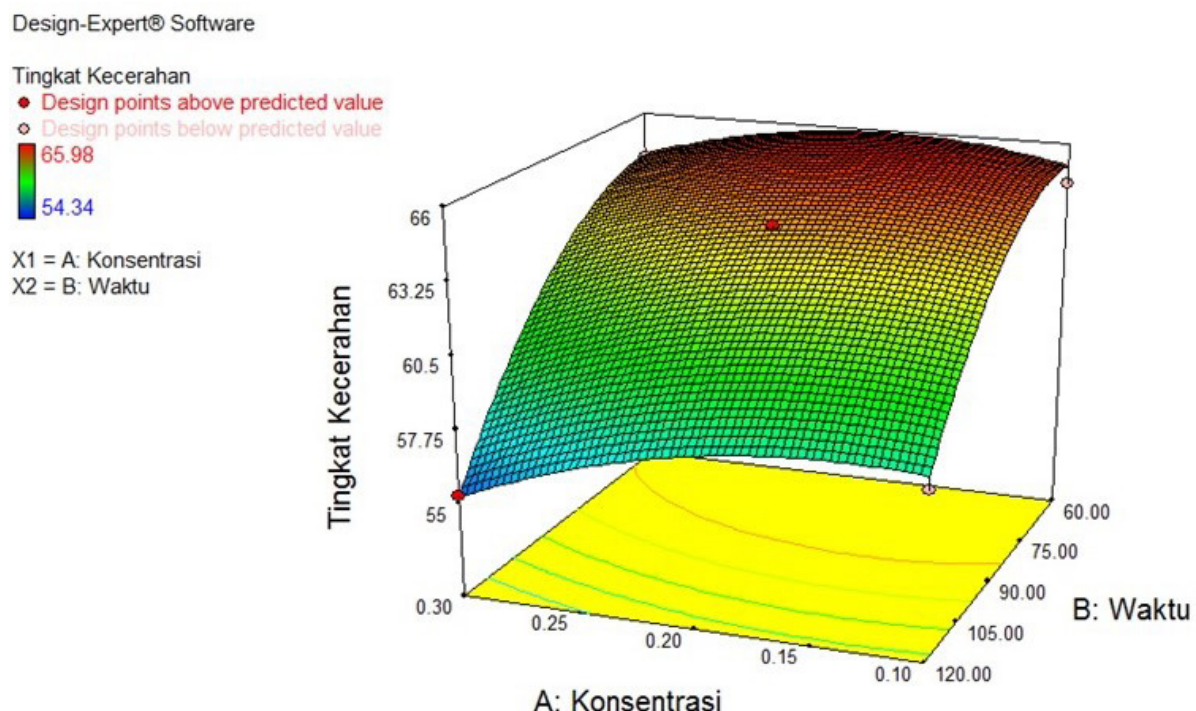

Gambar 3. Grafik interaksi 3-D terhadap tingkat kecerahan pektin 
kuadratik merupakan terpilih untuk menjelaskan hubungan antara faktor konsentrasi asam oksalat dengan lama waktu ekstraksi terhadap respon tingkat kecerahan pektin. Hasil analisa ragam (ANOVA) respon tingkat kecerahan pektin menunjukkan bahwa model kuadratik adalah model yang sesuai dengan respon tingkat kecerahan pektin. Hal ini ditunjukkan oleh p-value yang memiliki nilai kurang dari $5 \%$ atau $<0,05$ yaitu sebesar $<0,0001$, artinya model kuadratik memberikan pengaruh yang signifikan terhadap respon tingkat kecerahan pektin. Setelah itu, didapatkan Persamaan (3) model kuadratik terhadap respon tingkat kecerahan pektin.

$Y=+51,80946+51,74603 X_{1}+0,30866 X_{2}-$ $0,17750 X_{1} X_{2}-113,06250 X_{1}^{2}-2,26181 E-003 X_{2}^{2}$

Keterangan :

$\mathrm{Y}=$ Tingkat Kecerahan Pektin (L),

$\mathrm{X}_{1}=$ Faktor konsentrasi (\%),

$X_{2}=$ Faktor waktu (menit)

Berdasarkan Persamaan (3), dapat disimpulkan bahwa faktor konsentrasi asam oksalat dengan lama waktu ekstraksi dapat meningkatkan nilai tingkat kecerahan pektin, hal ini ditunjukkan dengan koefisien regresi yang positif. Namun, nilai tingkat kecerahan pektin akan menurun dengan tingginya konsentrasi asam oksalat dan semakin lama waktu ekstraksi yang digunakan, hal ini ditunjukkan koefisien regresi yang negatif. Hal ini sejalan dengan grafik yang dihasilkan pada Gambar 3, semakin tinggi faktor konsentrasi asam oksalat dan semakin lama waktu ekstraksi akan menurunkan nilai tingkat kecerahan pektin. Namun, sebaliknya semakin rendah konsentrasi asam oksalat yang digunakan dan semakin cepat waktu ekstraksi maka akan menghasilkan nilai respon tingkat kecerahan pektin yang semakin tinggi.

Konsentrasi pelarut asam yang tinggi dapat melarutkan pigmen lebih banyak atau senyawa lain pada kulit buah selama proses ekstraksi. Hal ini menandakan konsentrasi asam yang semakin rendah tidak melarutkan pigmen atau senyawa yang tidak diinginkan dengan sempurna, sehingga tingkat kecerahan pektin yang dihasilkan semakin tinggi (Leong et al., 2016). Lamanya waktu ekstraksi dengan paparan suhu yang tinggi dapat menyebabkan degradasi pigmen dan da- pat menimbulkan adanya senyawa polifenol (Khan et al., 2010; Marsiglia, 2016). Keberadaan polifenol atau adanya pigmen yang larut air dapat menurunkan tingkat kecerahan pektin (Faruque et al., 2016). Senyawa polifenol dapat teroksidasi oleh cahaya radiasi ataupun suhu. Polifenol yang teroksidasi akan membentuk senyawa o-kuinon, dimana senyawa ini yang menghasilkan pigmen warna coklat (Dong et al., 2016). Warna coklat yang dihasilkan ini akan menurunkan tingkat kecerahan pektin.

\section{Solusi Optimasi Ekstraksi Pektin}

Solusi optimasi terhadap respon rendemen, total pektin, dan tingkat kecerahan diperoleh dengan menentukan kriteria faktor dan respon yang ditentukan. Kriteria faktor konsentrasi asam dan lama waktu ekstraksi yang dipilih yaitu in range karena diharapkan proses ekstraksi dilakukan pada konsentrasi asam oksalat dan lama waktu ekstraksi mendekati titik tengah atau titik optimum. Pada kriteria respon yang dipilih yaitu maximize, karena masing-masing respon diharapkan memiliki nilai maksimum yang mendekati nilai batas atas setiap respon. Hasil optimasi yang diberikan progam Design Expert 7.1.5 terdapat satu solusi optimasi ekstraksi pektin. Solusi yang diberikan progam memiliki desirability sebesar 0,87 atau tingkat ketepatan nilai prediksi dengan nilai optimasi sebesar 0,87. Hasil solusi yang diberikan Design Expert dapat dilihat pada Tabel 2.

\section{Verifikasi Hasil Optimasi}

Tahap verifikasi dilakukan sebanyak 3 kali untuk mendapatkan solusi yang aktual. Perbandingan dilakukan menggunakan uji Paired T-test menggunakan Minitab 17. Hasil verifikasi dapat dilihat pada Tabel 3. Berdasarkan data yang dihasilkan, nilai $\mathrm{P}$ pada ketiga respon menunjukkan hasil lebih dari 0,05 yaitu $0,234,0,144$, dan 0,201 , hal tersebut menunjukkan bahwa ketiga respon memiliki nilai prediksi dan nilai penelitian yang tidak berbeda nyata (not significant). Hal ini mengindikasikan bahwa model sudah sesuai dan solusi variabel bebas yang diberikan software dapat diterima.

\section{Karakterisasi Pektin Hasil Optimasi}

Karakterisasi terhadap pektin yang diekstrak dengan hasil optimasi menggunakan konsentrasi asam oksalat 0,22\% dan lama waktu ekstraksi 90,27 menit. Karakterisasi pektin dilakukan untuk mengetahui 
karakteristik dari pektin hasil optimasi, meliputi kadar air, berat ekivalen, kadar metoksil, kadar asam galakturonat, dan derajat esterifikasi. Karakterisasi pektin hasil optimasi sudah sesuai dengan nilai standar mutu pektin berdasarkan International Pectin Producers Association (IPPA), kecuali pada berat ekivalen. Hal ini dapat disebabkan oleh metode ekstraksi yang digunakan dan jenis jeruk yang digunakan berbeda. Selain itu, peningkatan atau pengurangan berat ekivalen pada pektin dapat dipengaruhi oleh banyaknya jumlah asam bebas pada pektin (Devi et al., 2014). Nilai berat equivalen yang lebih rendah atau lebih tinggi dari range nilai standar menunjukkan bahwa ada ketidakmurnian pektin sehingga nilainya dipengaruhi juga oleh senyawa pengotor. Pektin yang dihasilkan termasuk pektin metoksil rendah. Pektin metoksil rendah biasanya digunakan dalam pembuatan saus salad, puding, gel buah dalam es krim, selai, dan jeli berkalori rendah dan untuk orang yang menghindari gula, serta pektin bermetoksil rendah dapat digunakan sebagai biosorben logam berat (Kurniasari et al., 2012). Hasil karakterisasi pektin optimasi dapat dilihat pada Tabel 4 .

\section{SIMPULAN}

Kondisi optimum proses ekstraksi pektin dari kulit jeruk manis yang didapatkan yaitu dengan konsentrasi asam oksalat 0,22\% (v/v) dan lama waktu ekstraksi 90,27 menit (90 menit 16 detik) menghasilkan nilai respon sebesar $16,78 \%$ untuk rendemen pektin, 10,59\% untuk total pektin, dan 63,56 untuk nilai kecerahan warna (L) pektin. Nilai hasil karakterisasi pektin optimasi berdasarkan kadar air, berat ekivalen, kadar metoksil, kadar asam galakturonat, dan derajat esterifikasi. Hasil yang didapatkan secara berturutturut sebesar 9,87\%; 901,60; 5,59\%; 51,45\%; $61,69 \%$. Pektin yang dihasilkan sudah sesuai dengan standar International Pectin Producers Association (IPPA), kecuali pada berat ekivalen. Pektin hasil optimasi termasuk pektin metoksil rendah.

\section{DAFTAR PUSTAKA}

AOAC. 1984. Official Methods of Analysis Association of Official Analytical Cheniata 14th edition. Washington DC, AOAC International
AOAC. 2005. Official Methods of Analysis. Washington DC, AOAC International

Budiyarti, -L., Fitriana, E, -N., Tuhuloula, -A., 2013. Karakteristik pektin dengan memanfaatkan kulit pisang menggunakan metode ekstraksi. Konversi. 2(1), 21-27. http:/ / dx.doi.org/10.20527/k.v2i1.123

Devi, W, -E., Shukla, R, -N., Bala, K, -L., Kumar, -A., Mishra, A, -A., Yadav, K, -C., 2014. Extraction of pectin from citrus fruit peel and its utilization in preparation of jelly. International Journal of Engineering Research and Technology. 3(5), 19251932. https://www.ijert.org/research/ extraction-of-pectin-from-citrus-fruitpeel-and-its-utilization-in-preparationof-jelly-IJERTV3IS051885.pdf

Dong, -X., Zhang, Y, -L., Wang, -F., Pang, M, -X., Qi, J, -H., 2016. Relationship in between chemical oxidation dan browning flavanols. IOP Earth and Enviromental Science. 41(2016), 1-9. https://iopscience.iop.org/article/10.1088/1755-1315/41/1/012012

Fakayode, O, -A., Abobi, K, -E., 2018. Optimization of oil and pectin extraction from orange (Citrus sinensis) peels: a response surface approach. Jurnal of Analytical Science and Technology. 9(20), 1-16. https:/ / doi.org/10.1186/s40543-018-0151-3

Faruque, M, -O., Kamrul, -N., Begum, -A., Mazumder, -M., Burhanuddin, -M., 2016. Effect of extraction methods on the characteristics of pectin from mango peel wastes. International Journal of Agricultural and Food Science. 6(2), 70-75. https://www.researchgate.net/publication/316471750_Effect_of_extraction_methods_on_the_characteristics_ of_pectin_from_mango_peel_wastes

Ismail, N, S, -M., Ramli, -N., Hani, N, -M., Meon, -Z., 2012. Extraction and characterization of pectin from dragon fruit (Hylocereus polyrhizus) using various extraction conditions. Sains Malaysiana. 41(1), 41-45. https:// www.ukm.my/jsm/pdf_files/SMPDF-41-1-2012/05\%20Norazelina.pdf

Kanse, N, -G., Chirag, -S., Swapnil, -S., Vishal, -S., 2017. Extraction of pectin from orange peel's and its Applications: Review. International Journal of Innovative Research in Science, Engineering and Technology. 6(9), 19452-19457. http://www.ijirset. com/upload/2017/september/142_51_ Paper\%20ID\%20IJ60909678\%20_1_.pdf 
Jurnal Teknologi Pertanian Vol. 22 No. 1 [April 2021] 47-56

Optimasi Konsentrasi Pelarut dan Waktu Ekstraksi Pektin Kulit Jeruk Manis [Putri dkk]

Khan, M, -K., Abert-Vian, -M., Fabiano-Tixier, A, -S., Dangles, -O., Chemat, -F., 2010. Ultrasound-assisted extraction of polyphenols (flavanone glycosides) from orange (Citrus sinensis L.) peel. Food Chemistry. 119(2), 851-858. https:/ / doi. org/10.1016/j.foodchem.2009.08.046

Kurniasari, -L., Riwayanti, -I., Suwardiyono. 2012. Pektin sebagai alternatif bahan baku biosorben logam berat. Momentum. 8(1), 1-5. http://dx.doi. org/10.36499/jim.v8i1.278

Kusnandar, F. 2011. Kimia Pangan Komponen Makro. Dian Rakyat, Jakarta

Kute, A, -B., Mohapatra, -D., Kotwaliwale, -N., Giri, S, -K., Sawant, B, -P., 2019. Characterization of pectin extracted from orange peel powder using microwave-assisted and acid extraction methods. Agricultural Research. 9, 241248. https://doi.org/10.1007/s40003019-00419-5

Leong, C, -M., Noranizan, M, -A., Kharidah, -M., Choo, W, -S., 2016. Physicochemical properties of pectin extracted from jackfruit and chempedak fruit rinds using various acids. International Food Research Journal. 23(3), 973-978. http:/ / www.ifrj.upm.edu.my/23\%20(03)\%20 2016/(9).pdf

Marsiglia, D, -E., Ojeda, K, -A., Ramirez, M, -C., Sanchez, -E., 2016. Pectin extraction from cocoa and husk (Theobroma cacaco L.,) by hydrolysis with citric and acetic acid. International Journal of Chem Tech Research. 9(7), 497-507. http:// sphinxsai.com/2016/ch_vol9_no7/2/ (497-507)V9N7CT.pdf

Nuh, -M., 2017. Pengaruh suhu dan lama ekstraksi terhadap mutu pektin kulit pisang kepok. Wahana Inovasi. 6(2), 144-148. http:/ / penelitian.uisu.ac.id/wp-content/ uploads/2017/09/8.-Mhd.-Nuh.pdf

Nurhayati., Maryanto., Tafrikhah, -R., 2016. Ekstraksi pektin dari kulit dan tandan pisang dengan variasi suhu dan metode. AGRITECH. 36(3), 327-334. https://doi.org/10.22146/agritech.16605
Patrignani, F., Rossi, S., Vannini, L., Lanciotti, R., 2021. 'High-Pressure Homogenization Effects on Spoilage and Pathogenic Microorganisms in Foods'. Dalam K Knoerzer, K Muthukumarappan (eds). Innovative Food Processing Technologies, A comprehensive Review. Elsevier

Pereira, P, H, -F., Oliveira, T, I, -S., Rosa, M, -F., Cavalcante, F, -L., Moates, G, -K., Wellner, -N., Waldron, K, -W., Azeredo, H, M, -C., 2016. Pectin extraction from pomegranate peels with citric acid. International Journal of Biological Macromolecules. 88, 373379. https://doi.org/10.1016/j.ijbiomac.2016.03.074

Perina, -I., Satiruiani., Soetardjo, F, -E., Hindarso, -H., 2007. Ekstraksi pektin dari berbagai macam kulit jeruk. Widya Teknik. 6(1), 1-10. http://journal.wima.ac.id/index.php/teknik/article/download/1227/pdf

Renggana. 1997. Manual Analysis of Fruits and Vegetables Product. New Delhi, Tata McGraw-Hill

Rosalina, -Y., Laili, -S., Noveriani, B, -K., 2017. Kajian ekstraksi pektin dari limbah jeruk rimau gerga lebong (Jeruk RGL) dan jeruk kalamansi. Agrointek, Jurnal Teknologi Industri Pertanian. 11(2), 6874. https://doi.org/10.21107/agrointek.v11i2.3174

Windiarsih, C., Nugroho, W, -A., Argo, B, A., 2015. Optimasi pektin dari kulit buah nangka (Artocarpus heterophyllus) dengan microwave assisted extraction (MAE) (kajian waktu ekstraksi dan konsentrasi pelarut). Jurnal Bioproses Komoditas Tropis. 3(1), 39-49. https:// jbkt.ub.ac.id/index.php/jbkt/article/ view/167/152

Ziari, -H., Ashtiani, F, -Z., Mohtashamy, -M., 2010. Comparing the effectiveness of processing parameters in pectin extraction from apple pomace. Afinidad. 67(549), 374-379. https://core.ac.uk/ download/pdf/39152307.pdf 